\title{
Design and evaluation of moxifloxacin hydrochloride ocular inserts
}

PRAVIN K. PAWAR ${ }^{1 *}$

RAJESH KATARA ${ }^{2}$

DIPAK K. MAJUMDAR ${ }^{2}$

${ }^{1}$ Chitkara College of Pharmacy, Chitkara University, Chandigarh-Patiala National Highway, Rajpura, Rajpura-140401

Patiala, Punjab, India

2 Department of Pharmaceutics, Delhi Institute of Pharmaceutical Sciences and Research (formerly College of Pharmacy) University of Delhi, Pushp Vihar Sector III, New Delhi-110017, India
The objective of the present investigation was to prepare and evaluate ocular inserts of moxifloxacin. An ocular insert was made from an aqueous dispersion of moxifloxacin, sodium alginate, polyvinyl alcohol, and dibutyl phthalate by the film casting method. The ocular insert (5.5 $\mathrm{mm}$ diameter) was cross-linked by $\mathrm{CaCl}_{2}$ and was coated with Eudragit S-100, RL-100, RS-100, E-100 or $\mathrm{L}-100$. The in vitro drug drainage/permeation studies were carried out using an all-glass modified Franz diffusion cell. The drug concentration and mucoadhesion time of the ocular insert were found satisfactory. Cross-linking and coating with polymers extended the drainage from inserts. The cross-linked ocular insert coated with Eudragit RL-100 showed maximum drug permeation compared to other formulations.

Keywords: moxifloxacin, ocular insert, goat cornea

Accepted December 16, 2011

Eyes are among the most readily accessible organs in terms of location in the body. The physiological constraints of the eye render this organ impervious to foreign substances, thus presenting a constant challenge to the formulator to circumvent the protective barriers of the eye without causing permanent tissue damage (1). All ocular therapeutics have been mostly administered to the eye as simple aqueous eye drops. About $90 \%$ of the dose applied topically from such solutions is lost due to pre-corneal losses (lacrimation and drainage), which leads to poor availability and frequent dosing is required for the instillation to achieve an adequate level and therapeutic effect (2). The standard treatment of severe bacterial keratitis requires frequent administration of fluoroquinolone eye drops (3). However, this regimen is not only disruptive to the patient and usually necessitates hospitalization, but it has also been associated with toxicity to the corneal epithelium $(4,5)$. To overcome these limitations, ocular inserts seem promising by prolonging the contact time with improved efficiency of the therapy and patient compliance. Ocular inserts offer many advantages over conventional dosage forms, like

\footnotetext{
* Correspondence; e-mail: pkpawar80@yahoo.com
} 
increased ocular residence, possibility of releasing drugs at a slow and constant rate, accurate dosing, and avoidance of toxicity due to preservative and increased shelf life (6). Ocular inserts of ciprofloxacin hydrochloride (7) and ofloxacin (8) have been designed to improve ocular availability.

Moxifloxacin, [1-cyclopropyl-6-fluoro-1,4-dihydro-8-methoxy-7-[(4aS,7aS)-octahydro$6 \mathrm{H}$-pyrrolol $(3,4 b)$ pyridin-6-yl]-4-oxo-3-quinoline carboxylic acid], is a fourth generation fluoroquinolone with a methoxy group at the $\mathrm{C}-8$ position and a bulky $\mathrm{C}-7$ side chain (9). Moxifloxacin has increased activity against $S$. aureus compared to second and third generation fluoroquinolones. Bactericidal activity of moxifloxacin is mediated by the inhibition of DNA gyrase (topoisomerase II) and topoisomerase IV, essential enzymes involved in bacterial DNA replication, transcription, repair and recombination (10). Effects of the formulation factor on in vitro corneal permeation of moxifloxacin from aqueous drops have been investigated and the results showed that moxifloxacin $0.5 \%(\mathrm{~m} / \mathrm{V})$ ophthalmic solution ( $\mathrm{pH} 7.2)$ containing benzalkonium chloride $(0.01 \%)(B A K)$ and EDTA $(0.01 \%)$ provides maximum in vitro ocular availability through all excised mammalian corneas (11). The in vitro permeation profile of moxifloxacin oil drops has been reported (12). Oil drops containing castor oil with benzyl alcohol provided maximum in vitro permeation through all the corneas. Aqueous and oily drops of moxifloxacin showed better permeation characteristics but these formulations require frequent instillation to achieve therapeutic concentration due to shorter precorneal residence time. Taking the above information in account, the purpose of the current study was to formulate ocular inserts of moxifloxacin that would be capable of prolonging the contact time, thereby potentially enhancing intra-corneal delivery of ophthalmic medicament.

\section{EXPERIMENTAL}

\section{Materials}

Moxifloxacin hydrochloride (99.97\% purity on anhydrous basis) was obtained from Ranbaxy Laboratories (India) as a gift. Sodium alginate, Eudragit S-100 (anionic methacrylic acid-methyl methacrylate copolymer), Eudragit RL-100 (acrylic acid and methacrylic acid ester copolymer containing $10 \%$ trimethylammonium methacrylate chloride), Eudragit RS-100 (acrylic acid methacrylic acid ester copolymer containing $5 \%$ trimethylammonium methacrylate chloride), Eudragit E-100 (cationic polymer based on dimethylaminoethyl methacrylate and other neutral methacrylic acid esters), Eudragit L-100 (anionic copolymer based on methacrylic acid and methyl methacrylate) were obtained from Jubilant Organosys (India) as gift samples. Polyvinyl alcohol (PA) and dibutyl phthalate were obtained from the Central Drug House (India) and S.D. Fine chemicals Ltd (India), respectively. All other chemicals were of analytical grade. Fresh goat eyeball was obtained from a butcher's shop. The method of cornea dissection and the apparatus used in permeation studies were the same as described previously (13). 


\section{Preparation of ocular inserts}

The moxifloxacin control ocular insert (MIF1) was made from an aqueous dispersion $(40 \mathrm{~mL})$ of moxifloxacin hydrochloride $(400 \mathrm{mg})$, sodium alginate $(0.25 \mathrm{~g})$, polyvinyl alcohol (PVA) $(1.5 \mathrm{~g})$, and dibutyl phthalate $(0.3 \mathrm{~mL})$ by the film casting method. Ocular insert (5.5 mm diameter) was cross-linked (MIF2) by $\mathrm{CaCl}_{2}(0.2 \%, \mathrm{~m} / \mathrm{N})$ by dipping and drying 5 times. Similarly, the cross-linked insert was coated with different grades of Eudragit polymer $0.2 \%(\mathrm{~m} / \mathrm{V})$ in isopropyl alcohol and acetone by the dip and dry method (Table I). The polymers used were Eudragit S-100 (MIF3), Eudragit RL-100 (MIF4), Eudragit RS-100 (MIF5), Eudragit E-100 (MIF6) and Eudragit L-100 (MIF7). The mass gain of the ocular insert after coating with polymer was found to be in the range $23.4-29.6 \%$.

Table I. Compositions of moxifloxacin insert formulations for ocular delivery

\begin{tabular}{ccccc}
\hline Formulation & $\begin{array}{c}\text { Polymer composition } \\
(18+12+70 \%, m / m)\end{array}$ & $\begin{array}{c}\text { Plasticizer (dibutyl } \\
\text { phthalate, } \%, V / V)\end{array}$ & $\begin{array}{c}\text { Cross-linking agent } \\
\mathrm{CaCl}_{2}(\%, m / \mathrm{V})\end{array}$ & $\begin{array}{c}\text { Coating material } \\
(0.2 \%, m / \mathrm{V})\end{array}$ \\
\hline MIF1 & MOX + SA + PVA & 0.12 & - & - \\
MIF2 & MOX + SA + PVA & 0.12 & 0.2 & - \\
MIF3 & MOX + SA + PVA & 0.12 & 0.2 & Eudragit S-100 \\
MIF4 & MOX + SA + PVA & 0.12 & 0.2 & Eudragit RL-100 \\
MIF5 & MOX + SA + PVA & 0.12 & 0.2 & Eudragit RS-100 \\
MIF6 & MOX + SA + PVA & 0.12 & 0.2 & Eudragit E-100 \\
MIF7 & MOX + SA + PVA & 0.12 & 0.2 & Eudragit L-100 \\
\hline
\end{tabular}

MOX - moxifloxacin, SA - sodium alginate, PVP- polyvinyl alcohol

\section{Physicochemical evaluation of ocular inserts}

Thickness uniformity. - Insert thickness (5.5 mm diameter) was measured at five different points using a Micrometer screw gauge (Mitutoyo Co., Japan) and the mean insert thickness was noted $(n=3)$.

Drug content uniformity. - Three inserts were taken out of the film and drug concentration determined. The uncoated ocular insert was dissolved in $10 \mathrm{~mL}$ of $0.1 \mathrm{~mol} \mathrm{~L}^{-1}$ $\mathrm{HCl}$ while the coated insert was dissolved in $10 \mathrm{~mL}$ of acetone. The volume was made up to $100 \mathrm{~mL}$ with distilled water and the solution was filtered. The drug in the filtrate was analyzed by measuring absorbance at $291 \mathrm{~nm}$ in a spectrophotometer 1601 (Shimad$\mathrm{zu}$, Japan). The experiment was done in triplicate.

\section{Mucoadhesion time}

The mucoadhesion time was determined (in triplicate) after application of coated or uncoated ocular inserts (5.5 mm diameter, $0.40-0.45 \mathrm{~mm}$ thickness) on a freshly cut goat eyelid. The eyelid was fixed on the bottom of a beaker with cyanoacrylate glue. Ocular insert (coated or uncoated) was attached to the mucosal surface of the eyelid by apply- 
ing a light force with a fingertip for $20 \mathrm{~s}$. The beaker was filled with $800 \mathrm{~mL}$ of bicarbonate Ringer solution $\mathrm{pH} 7.4$ and stirred at a rate of $150 \mathrm{rpm}$ at room temperature (14). The time needed for complete detachment of the insert from the mucosal surface was considered as mucoadhesion time.

\section{Drug permeation}

The in vitro drug permeation studies were carried out by putting the ocular insert (5.5 $\mathrm{mm}$ in diameter) on Millipore membrane filter $(0.15 \mu \mathrm{m})$; between the donor and receptor compartments of an all-glass modified Franz diffusion cell. The Millipore membrane filter was used to simulate the corneal epithelial barrier as isolated cornea will not remain viable beyond $4 \mathrm{~h}$. To simulate the tear flow, the donor compartment was infused with bicarbonate Ringer, $\mathrm{pH} 7.4$, at a flow rate of $20 \mu \mathrm{L} \mathrm{min}{ }^{-1}$ throughout the study. The drained sample was monitored for moxifloxacin at $291 \mathrm{~nm}$ every hour. Similarly, a 1.0-mL sample was withdrawn at hourly intervals from the receptor compartment (containing $10 \mathrm{~mL}$ bicarbonate Ringer, $\mathrm{pH} 7.4$, under stirring at $37^{\circ} \mathrm{C}$ ) and the drug permeated was measured. Each withdrawn sample was replaced with an equal volume of fresh bicarbonate Ringer. Drug permeation experiments were also carried out using freshly excised goat cornea for $4 \mathrm{~h}$. At the end of the experiment, each cornea (freed from adhering sclera) was weighed, soaked in $1 \mathrm{~mL}$ of methanol, dried overnight at $90{ }^{\circ} \mathrm{C}$ and reweighed. Corneal hydration was calculated from the difference in masses.

The drug permeation data was plotted according to zero-order, first-order kinetics, Higuchi equation and Korsmeyer-Peppas equation (15).

\section{Fourier transform infrared (FTIR) spectroscopy}

The FTIR spectra of the pure drug and physical mixture (moxifloxacin, polyvinyl alcohol and sodium alginate) were taken as $\mathrm{KBr}$ pellets in the range of $4000-650 \mathrm{~cm}^{-1}$ (Perkin Elmer Model 1600 FT-IR spectrophotometer, USA). The infrared analysis of all inserts was carried out in the same range by ATR-IR spectroscopy (Perkin Elmer Model 1600 FT-IR spectrophotometer with ATR mode (Pike Miracle ATR Accessory, Perkin Elmer, USA).

\section{In vivo study}

Selected ocular inserts (MIF4 and MIF5) sterilized using $\gamma$-irradiation were used for in vivo drug release studies. The protocol on the use of animals (albino rabbits) was approved by the Institutional Ethics Committee. Two groups of ten healthy albino rabbits were used to study the drug release in vivo from formulations that showed satisfactory in vitro drug release (16). Each rabbit was kept under good hygienic conditions in order to avoid vulnerability to any disease, including ophthalmic types. Selected ocular inserts were placed in the cul-de-sac of each rabbit while the other eye served as a control. At periodic intervals (1-10 h) the inserts were taken out carefully from the cul-de-sac of each rabbit and analyzed for the remaining drug content. The remaining drug was subtracted from the initial drug content of the insert, which gave the amount of drug released in the rabbit eye. 


\section{Stability of ocular inserts}

Stability studies were carried out on ocular insert formulations according to ICH guidelines (17). A sufficient number of ocular inserts (packaged in aluminum foils) were stored in a humidity chamber with a relative humidity of $75 \pm 5 \%$ and temperatures of $40 \pm 2{ }^{\circ} \mathrm{C}$ or at room temperature. Samples were withdrawn at time 0, 3 weeks, 6 weeks, 3 months and 6 months. Ocular inserts were also evaluated for their physical characteristics (color) and analyzed for drug concentration. The degradation rate constant was determined from the plot of logarithm of the remaining drug vs. time.

\section{RESULTS AND DISCUSSION}

\section{Physicochemical evaluation and mucoadhesion time of ocular inserts}

The thickness of ocular inserts was found to be from $0.40 \pm 0.00$ to $0.45 \pm 0.06$ millimeters. Drug concentration of the ocular insert without cross-linking and uncoated (control MIF1) was maximum (i.e., $0.149 \mathrm{mg} \mathrm{mm}^{-2}$ ), followed by the cross-linked ocular insert (i.e., $0.122 \mathrm{mg} \mathrm{mm}^{-2}$ ) and coated ocular insert (i.e., $0.115 \mathrm{mg} \mathrm{mm}^{-2}$ ) (Table II). Inserts were supposed to be retained in the lower conjunctival cul-de-sac and accordingly the mucoadhesive property of the inserts was evaluated. The mucoadhesion time of various ocular inserts was found to be $0.32-1.07 \mathrm{~h}$. Control ocular inserts showed maximum mucoadhesion, which appears to be due to the presence of hydroxyl groups in the inserts (contributed by PVA and alginate), which could form hydrogen bonding with the mucosa. Cross-linking by $\mathrm{CaCl}_{2}$ reduced the mucoadhesion. On coating with Eudragit polymers, cross-linked insert further reduced mucoadhesion as the surface hydroxyl group of the insert got coated with polymer having a carboxylic group and/or quaternary ammonium group. Thus, taking both mucoadhesion and sustained drug release into consideration, the cross-linked ocular insert coated with Eudragit RL-100 appears to be promising (Table II).

\section{Fourier transform infrared (FTIR) spectroscopy}

FTIR spectra of moxifloxacin hydrochloride (Fig. 1) showed aromatic $\mathrm{C}=\mathrm{C}$ stretching at 1621, 1515 and $1454 \mathrm{~cm}^{-1}$ and $\mathrm{C}-\mathrm{H}$ bending for substituted benzene at $873 \mathrm{~cm}^{-1}$. Besides, spectra also showed carboxylic acid $\mathrm{C}=\mathrm{O}$ stretching at $1705 \mathrm{~cm}^{-1}, \mathrm{C}-\mathrm{N}$ stretching at $1350 \mathrm{~cm}^{-1}$, stretching of monofluorobenzene at $1183 \mathrm{~cm}^{-1}$. Spectra of a physical mixture of the drug, PVA and sodium alginate showed peaks at $3520 \mathrm{~cm}^{-1}$ due to stretching of the hydroxyl group, $2920 \mathrm{~cm}^{-1}$ due to $\mathrm{C}-\mathrm{H}$ stretching and $1023 \mathrm{~cm}^{-1}$ due to $\mathrm{C}-\mathrm{O}-\mathrm{C}$ stretching (which appears to be contributed by PVA and alginate), along with drug peaks. The ATR spectra of the blank insert of PVA-alginate showed shifting of the hydroxyl peak from 3520 to $3306 \mathrm{~cm}^{-1}$ due to intermolecular hydrogen bonding, $\mathrm{C}-\mathrm{H}$ stretching at 2913 and $\mathrm{C}-\mathrm{O}-\mathrm{C}$ stretching at $1027 \mathrm{~cm}^{-1}$. Uncross-linked and cross-linked inserts showed hydroxyl stretching, $\mathrm{C}-\mathrm{H}$ stretching along with asymmetric $\mathrm{C}-\mathrm{O}-\mathrm{C}$ stretching at $1247 \mathrm{~cm}^{-1}$ and symmetric $\mathrm{C}-\mathrm{O}-\mathrm{C}$ stretching at 1090 and $1023 \mathrm{~cm}^{-1}$, indicating branching on the carbon atom adjacent to the oxygen atom. Besides, ATR spectra showed 


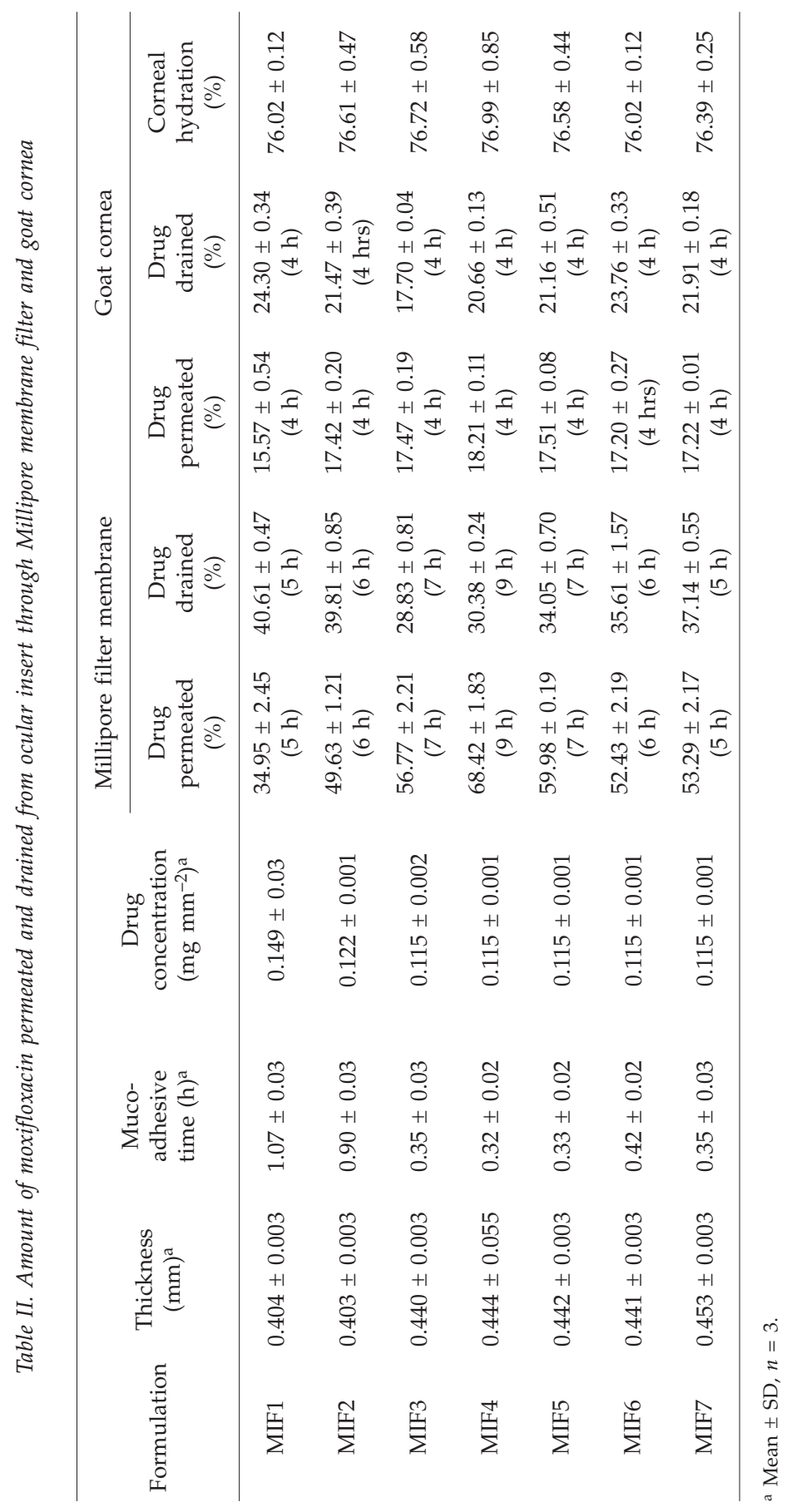




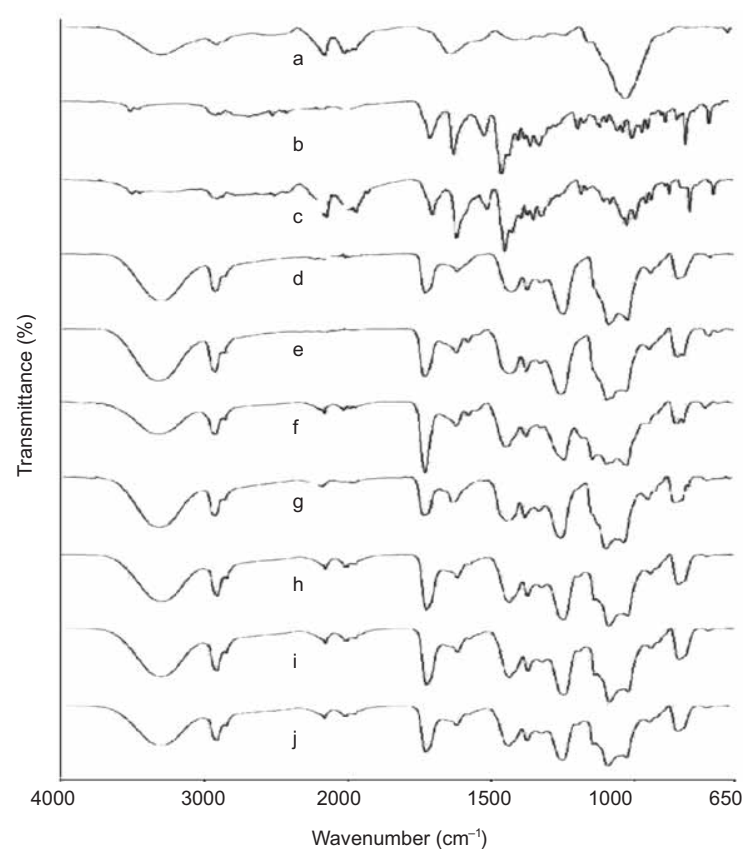

Fig. 1. FTIR spectra of: a) blank insert (without moxifloxacin), b) moxifloxacin, c) physical mixture of the drug, PVA and sodium alginate, d) control insert (not cross-linked and uncoated), MIF1, e) cross linked insert $\left.\left(\mathrm{CaCl}_{2}\right), \mathrm{MIF} 2, \mathrm{f}\right)$ optimal formulation (Eudragit RL-100), MIF4, g) Eudragit RS-100, MIF5, h) Eudragit S-100, MIF3, i) Eudragit E-100, MIF6, j) Eudragit L-100, MIF7.

aromatic $\mathrm{C}=\mathrm{C}$ stretching, $\mathrm{C}=\mathrm{O}$ stretching and $\mathrm{C}-\mathrm{N}$ stretching. All the coated inserts showed aromatic $\mathrm{C}=\mathrm{C}$ stretching at usual positions, indicating incorporation of moxifloxacin and peaks for ester at $1730 \mathrm{~cm}^{-1}$, since acrylate polymers are esters. It would be important to mention here that ATR spectra provide information on the surface functional groups. Major characteristic peaks of moxifloxacin were found in the entire coated ocular insert, confirming the presence of the drug in the polymer without interaction.

\section{In vitro/ex vivo permeation study}

The results are shown in Table II, indicating that the in vitro drug release from the plain ocular insert (control) was sustained for $5 \mathrm{~h}$. The drug release from MIF2 was extended up to $6 \mathrm{~h}$. Formulation MIF6 did not have any effect on drug release, while MIF3 and MIF5 could sustain drug release up to $7 \mathrm{~h}$. After coating with different grades of Eudragit, drug release from ocular inserts was found to be sustained due to the presence of polymeric film. Among all formulations, MIF4 showed the best sustaining effect. The MIF4 formulation gave $68.4 \%$ drug permeated through the Millipore membrane filter after 9 hours. 
To mimic real life conditions, permeation studies were then conducted with freshly excised goat cornea and the results are shown in Table II. Considering cornea viability, the experiment was conducted for $4 \mathrm{~h}$ and the drug permeation from inserts ranged between 15.6 and $17.5 \%$, which was less than the permeation observed with the Millipore membrane filter in $4 \mathrm{~h}$. Millipore membrane filter acts as a mechanical barrier to drug diffusion while cornea [made of epithelium (lipophilic), stroma (hydrophilic), and endothelium (less lipophilic than epithelium)] acts as a lipophilic-hydrophilic barrier and the drug will have to partition through the barrier for corneal penetration. Accordingly, permeation through the cornea would be lower compared to that across the Millipore membrane filter. The corneal hydration level was found to be below $80 \%$ in each experiment, indicating the inserts would not cause any damage to the cornea.

The release profiles of ocular inserts were treated with the Korsmeyer-Peppas equation and slope values were $>0.89$, indicating super case II type of drug release from ocular inserts through the Milipore membrane filter and excised goat cornea (15). Thus, all formulations followed the Korsmeyer-Peppas kinetics model (Table III).

\section{In vivo drug release study}

Formulations MIF4 and MIF5 were selected for in vivo drug release studies on the basis of maximum mucoadhesion and better sustained behavior of the drug among all insert formulations. Ocular inserts were removed carefully at hourly intervals (from

Table III. Kinetics of in vitro drug release from ocular inserts through Millipore membrane filter and goat cornea

\begin{tabular}{|c|c|c|c|c|c|c|c|c|c|}
\hline \multirow{3}{*}{$\begin{array}{l}\text { Formu- } \\
\text { lation }\end{array}$} & \multicolumn{8}{|c|}{$R^{2}$} & \multirow{3}{*}{$\begin{array}{l}\text { Mechanism } \\
\text { of drug } \\
\text { release }^{\mathrm{a}}\end{array}$} \\
\hline & \multicolumn{2}{|c|}{ Zero-order ${ }^{\mathrm{a}}$} & \multicolumn{2}{|c|}{ First-order ${ }^{\mathrm{a}}$} & \multicolumn{2}{|c|}{ Higuchi $^{\mathrm{a}}$} & \multicolumn{2}{|c|}{ Korsmeyer-Peppas ${ }^{\mathrm{a}}$} & \\
\hline & $\begin{array}{l}\text { Millipore } \\
\text { membrane }\end{array}$ & $\begin{array}{l}\text { Goat } \\
\text { cornea }\end{array}$ & $\begin{array}{l}\text { Millipore } \\
\text { membrane }\end{array}$ & $\begin{array}{l}\text { Goat } \\
\text { cornea }\end{array}$ & $\begin{array}{l}\text { Millipore } \\
\text { membrane }\end{array}$ & $\begin{array}{l}\text { Goat } \\
\text { cornea }\end{array}$ & $\begin{array}{l}\text { Millipore } \\
\text { membrane }\end{array}$ & $\begin{array}{c}\text { Goat } \\
\text { cornea }^{a}\end{array}$ & \\
\hline MIF1 & 0.8482 & 0.9938 & 0.9432 & 0.9979 & 0.9877 & 0.9511 & 0.9988 & 0.9997 & $\begin{array}{c}\text { Non- } \\
\text {-Fickian }\end{array}$ \\
\hline MIF2 & 0.9781 & 0.9919 & 0.9622 & 0.9969 & 0.9871 & 0.9536 & 0.9992 & 0.9999 & $\begin{array}{l}\text { Non- } \\
\text {-Fickian }\end{array}$ \\
\hline MIF3 & 0.9444 & 0.9930 & 0.9634 & 0.9975 & 0.9831 & 0.9514 & 0.9963 & 1.000 & $\begin{array}{l}\text { Non- } \\
\text {-Fickian }\end{array}$ \\
\hline MIF4 & 0.9653 & 0.9926 & 0.9625 & 0.9983 & 0.9742 & 0.9515 & 0.9982 & 0.9993 & $\begin{array}{l}\text { Non- } \\
\text {-Fickian }\end{array}$ \\
\hline MIF5 & 0.9626 & 0.9922 & 0.9748 & 0.9978 & 0.9891 & 0.9537 & 0.9991 & 0.9999 & $\begin{array}{c}\text { Non- } \\
\text {-Fickian }\end{array}$ \\
\hline MIF6 & 0.9688 & 0.9889 & 0.9654 & 0.9950 & 0.9712 & 0.9577 & 0.9964 & 0.9999 & $\begin{array}{l}\text { Non- } \\
\text {-Fickian }\end{array}$ \\
\hline MIF7 & 0.9642 & 0.9938 & 0.9678 & 0.9979 & 0.9702 & 0.9511 & 0.9964 & 0.9997 & $\begin{array}{l}\text { Non- } \\
\text {-Fickian }\end{array}$ \\
\hline
\end{tabular}

a $n=3$. 
1-10 hours) and analyzed for residual drug content. The drug was subtracted from the initial content of the insert and gave the amount of drug released in the rabbit eye. Fig. 3 presents the cumulative drug release (\%) from formulations MIF4 and MIF5 at different time intervals. The in vivo study suggests the formulation MIF4 showed maximum cumulative drug release of $85.0 \%$ and release was sustained up to $10 \mathrm{~h}$. Formulation MIF5 showed $72.1 \%$ cumulative release which was sustained up to $8 \mathrm{~h}$. Also, formulation MIF4 had more tendency to stick to ocular mucosa due to the presence of higher concentration of quaternary ammonium groups (10 \%) in Eudragit RL-100 as compared to Eudragit RS-100 (5\%). The presence of quaternary ammonium groups renders positive charge to the polymers by which it can interact with anionic mucin and thereby increase its residence on corneal surface.

\section{Stability}

Finally, accelerated stability studies at elevated temperature and humidity revealed no significant changes in color in insert formulations. The moxifloxacin concentration in all formulations at accelerated and room temperature are shown in Fig. 2. The degradation rate constants $\left(k_{\mathrm{cal}}\right)$ and shelf life $\left(t_{90}\right)$ values for MIF1, MIF3, MIF5-MIF7 at room temperature were found to range between 2.12 and 1.69 days $^{-1}$, and 490-617 days. MIF2 and MIF4 showed lower degradation constants of 1.12 and 1.41 day $^{-1}$ and longer shelf life of 926 and 739 days, resp. The stability study concluded that formulations MIF2 and MIF4 showed the lowest degradation and maximum shelf life as per the ICH guidelines (17) suggest there is no need to add overages to ensure 2 year shelf life.

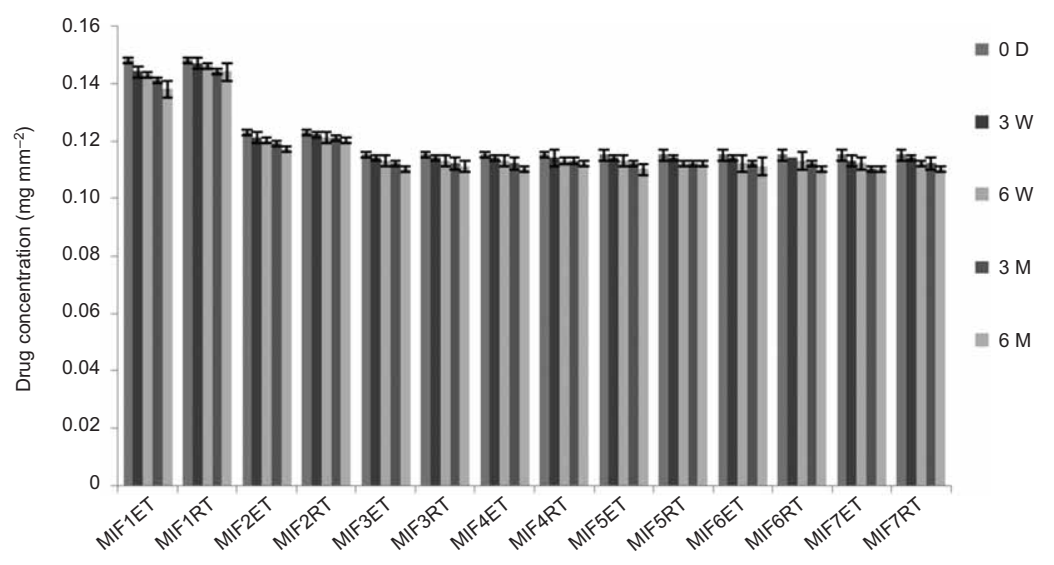

Fig. 2. Stability of moxifloxacin ocular inserts under accelerated condition and room temperature. Mean $\pm \mathrm{SD}(n=3)$. ET - elevated temperature $\left(40^{\circ} \mathrm{C}\right), \mathrm{RT}$ - room temperature, $\mathrm{D}$ - days, $\mathrm{W}$ - weeks, $\mathrm{M}-$ months. 


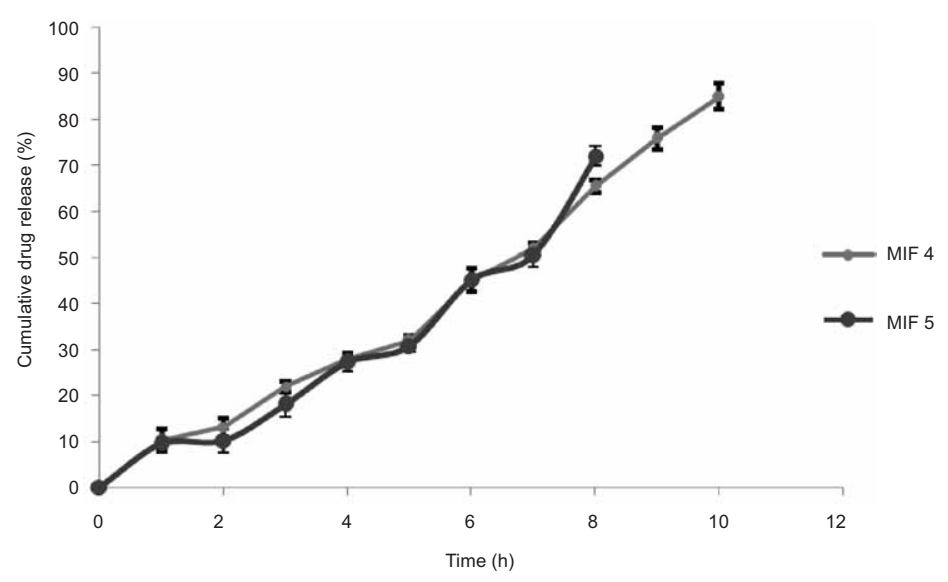

Fig. 3. In vivo moxifloxacin release profile from ocular inserts.

\section{CONCLUSIONS}

In conclusion, we suggest that the ocular insert formulation of moxifloxacin can be a promising vehicle for topical ocular administration of antibiotics. Its application could possibly replace the use of fortified solutions of antimicrobials and reduce the necessity for repeated drug administration at frequent intervals, thereby potentially lowering corneal toxicity and increasing patient compliance.

Acknowledgements. - The authors are thankful to Ranbaxy Laboratories Limited, Gurgaon, India, for donating the moxifloxacin hydrochloride bulk drug. The authors thank All India Council of Technical Education (New Delhi, India) for providing a National Doctoral Fellowship to Mr. Pravin Kondiba Pawar.

\section{REFERENCES}

1. E. Barbu, I. Sarvaiya, K. L. Green, T. G. Nevell and J. Tsibouklis, Vinylpyrrolidone-co-(meth) acrylic acid inserts for ocular drug delivery: synthesis and evaluation, J. Biomed. Mater. Res. 74 (2005) 598-606; DOI: 10.1002/jbm.a.30329.

2. N. Gangopadhyay, M. Daniell, L. Weih and H. Taylor, Fluoroquinolone and fortified antibiotics for treating bacterial corneal ulcers, Br. J. Ophthalmol. 84 (2000) 378-384; DOI: 10.1136/bjo.84.4.378.

3. A. P. Smith, M. Pennefather, S. B. Kaye and C. A. Hart, Fluoroquinolones: place in ocular therapy, Drugs 61 (2001) 747-761.

4. P. E. Cutarelli, J. H. Lass, H. M. Lazarus, S. C. Putman and M. R. Jacobs, Topical fluoroquinolones: antimicrobial activity and in vitro corneal epithelial toxicity, Curr. Eye Res. 10 (1991) 557-563; DOI: $10.3109 / 02713689109001764$. 
5. P. L. Mallari, D. J. McCarty, M. Daniell and H. Taylor, Increased incidence of corneal perforation after topical fluoroquinolone treatment for microbial keratitis, Am. J. Ophthalmol. 131 (2001) 131-133; DOI: 10.1016/S0002-9394(00)00642-5.

6. S. Barath and S. R. Hiremath, Ocular delivery system of perfloxacin mesylate, Pharmazie 54 (1999) $55-58$.

7. A. S. Mundada and B. K. Srikhande, Formulation and evaluation of ciprofloxacin hydrochloride soluble ocular drug insert, Curr. Eye Res. 33 (2008) 469-475; DOI: 10.1080/02713680802023104.

8. G. Di Colo, S. Burgalassi, P. Chetoni, M. P. Fiaschi, Y. Zambito and M. F. Saettone, Gel-forming erodible inserts for ocular controlled delivery of ofloxacin, Int. J. Pharm. 14 (2001) 101-111; DOI: 10.1016/S0378-5173(02)00421-0.

9. J. M. Woodcock, J. M. Andrews, F. J. Boswell, N. P. Brenwald and R. Wise, In vitro activity of BAY 12-8039, a new fluoroquinolone, Antimicrob. Agents Chemother. 41 (1997) 101-106.

10. E. Pestova, J. J. Millichap, G. A. Noskin and L. R. Peterson, Intracellular targets of moxacifloxacin: a comparison with other fluoroquinolones, J. Antimicrob. Chemother. 45 (2000) 583-590; DOI: $10.1093 / \mathrm{jac} / 45.5 .583$.

11. P. K. Pawar and D. K. Majumdar, Effect of formulation factors on in vitro permeation of moxifloxacin from aqueous drops through excised goat, sheep and buffalo corneas, AAPS PharmSci Tech. 7 (2006) E13.

12. P. K. Pawar and D. K. Majumdar, In vitro permeation characteristics of moxifloxacin from oil drops through excised goat, sheep, buffalo and rabbit corneas, Pharmazie 62 (2007) 853-857; DOI: 10.1691/PH.2007.11.7055.

13. M. Malhotra and D. K. Majumdar, In vitro transcorneal permeation of ketorolac tromethamine from buffered and unbuffered aqueous ocular drops, Indian J. Exp. Biol. 35 (1997) 941-947.

14. L. Perioli, V. Ambrogi, S. Giovagnoli, M. Ricci, P. Blasi and C. Rossi, Mucoadhesive bilayered tablets for buccal sustained release of flurbiprofen, AAPS PharmSciTech. 8 (2007) E54; DOI: $10.1208 / \mathrm{pt} 0803054$.

15. P. Costa and L. J. Manuel Sousa, Modeling and comparison of dissolution profiles, Eur. J. Pharm. Sci. 13 (2001) 123-133; DOI: 10.1016/S0928-0987(01)00095-1.

16. V. Shankar, A. K. Chandrasekaran, S. Durga, G. Geetha and V. A. Ravichandran, Design and evaluation of diclofenac sodium ophthalmic inserts, Acta Pharm. Sci. 48 (2006) 5-10.

17. International Conference on Harmonization, Q1A (R2): Stability Testing of New Drug Substances and Products, ICH, Geneva 2003.

\section{Dizajniranje i vrednovanje okularnih umetaka moksifloksacin hidroklorida}

PRAVIN K. PAWAR, RAJESH KATARA i DIPAK K. MAJUMDAR

Cilj rada bio je priprava i evaluacija okularnih umetaka moksifloksacina. Okularni umetak izrađen je od vodene suspenzije moksifloksacina, natrijevog alginata, polivinilnog alkohola i dibutil-ftalata metodom odlijevanja filma. Okularni umetak (promjera 5,5 mm) umrežen je pomoću $\mathrm{CaCl}_{2}$ i obložen Eudragitom S-100, RL-100, RS-100, E-100 ili Eudragit L-100. In vitro drenaža/permeacija lijeka proučavana je koristeći staklenu modificiranu Franzovu difuzijsku ćeliju. Koncentracija lijeka i vrijeme mukoadhezije oku- 
larnih umetaka bili su zadovoljavajući. Umrežavanje i oblaganje polimerima produljilo je drenažu iz umetaka. Umreženi okularni umetci obloženi s Eudragit RL-100 pokazali su veću permeaciju lijeka u odnosu na ostale pripravke.

Ključne riječi: moksifloksacin, okularni umetak, kornea koze

Chitkara College of Pharmacy, Chitkara University, Chandigarh-Patiala National Highway, Rajpura, Rajpura-140401, Patiala, Punjab, India

Department of Pharmaceutics, Delhi Institute of Pharmaceutical Sciences and Research, (formerly College of Pharmacy), University of Delhi, Pushp Vihar, Sector III, New Delhi-110017, India 